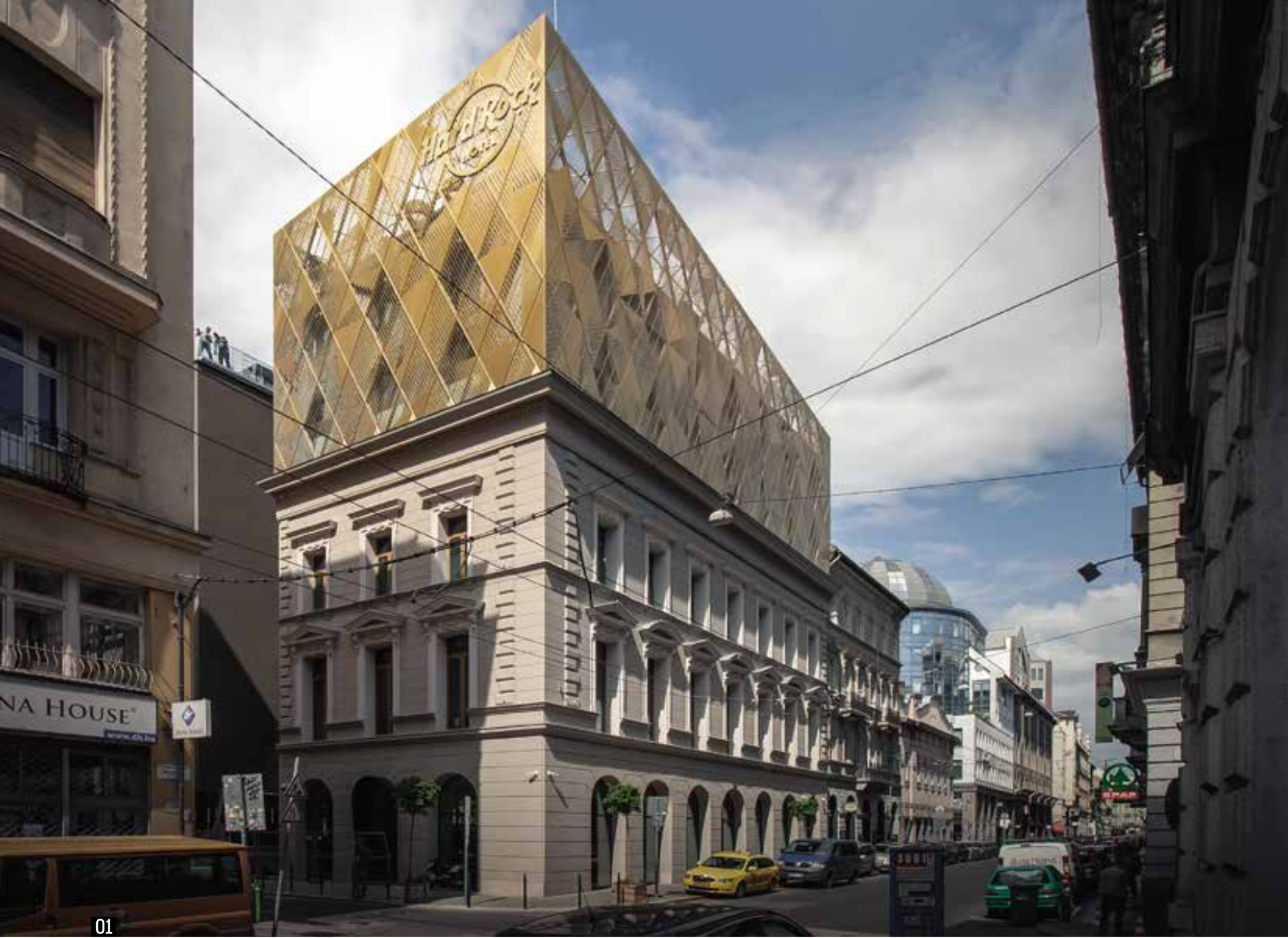

\title{
ÁTHANGSZERELT FINÁLÉ
}

\author{
HARD ROCK HOTEL | BUDAPEST, NAGYMEZÖ UTCA
}

\section{MÚLT}

_ A Stúdió’Ioo építészcsapata 2008-ban, meghívásos tervpályázat keretében nyerte el a tervezési feladatot. A meghívottak szűk körébe a Clark Hotel 2007-es, nemzetközi pályázatán aratott sikerük nyomán kerültek.

_ Bár az érvényes szabályozási terv alapján a telken meglévő épületek egyike sem élvezett védettséget, a kétemeletes saroképület utcai traktusának megtartása a koncepció egyik alapelemévé vált. Az I870-es 01 években épült lakóház a századforduló eklektikus építészetének jellegzetes - igaz, nem kiemelkedően értékes - példája. Az utóbbi évtizedek során rárakódott ad hoc elemek felszámolásával azonban a gazdagon díszített homlokzat harmonikus arányrendszere és finom részletgazdagsága még inkább szembetűnővé vált.

_ Az Ó utca két, erősen leromlott állapotú épületének helyére a tervezési terület telekösszevonásaival új, összefüggó épületszárny került, amely szúk átriumával egyszerre idézi Belső-Terézváros karakteresen feszes, tűzfalakkal tűzdelt udvarait, miközben racionális alaprajzi elrendezést tesz lehetővé. 


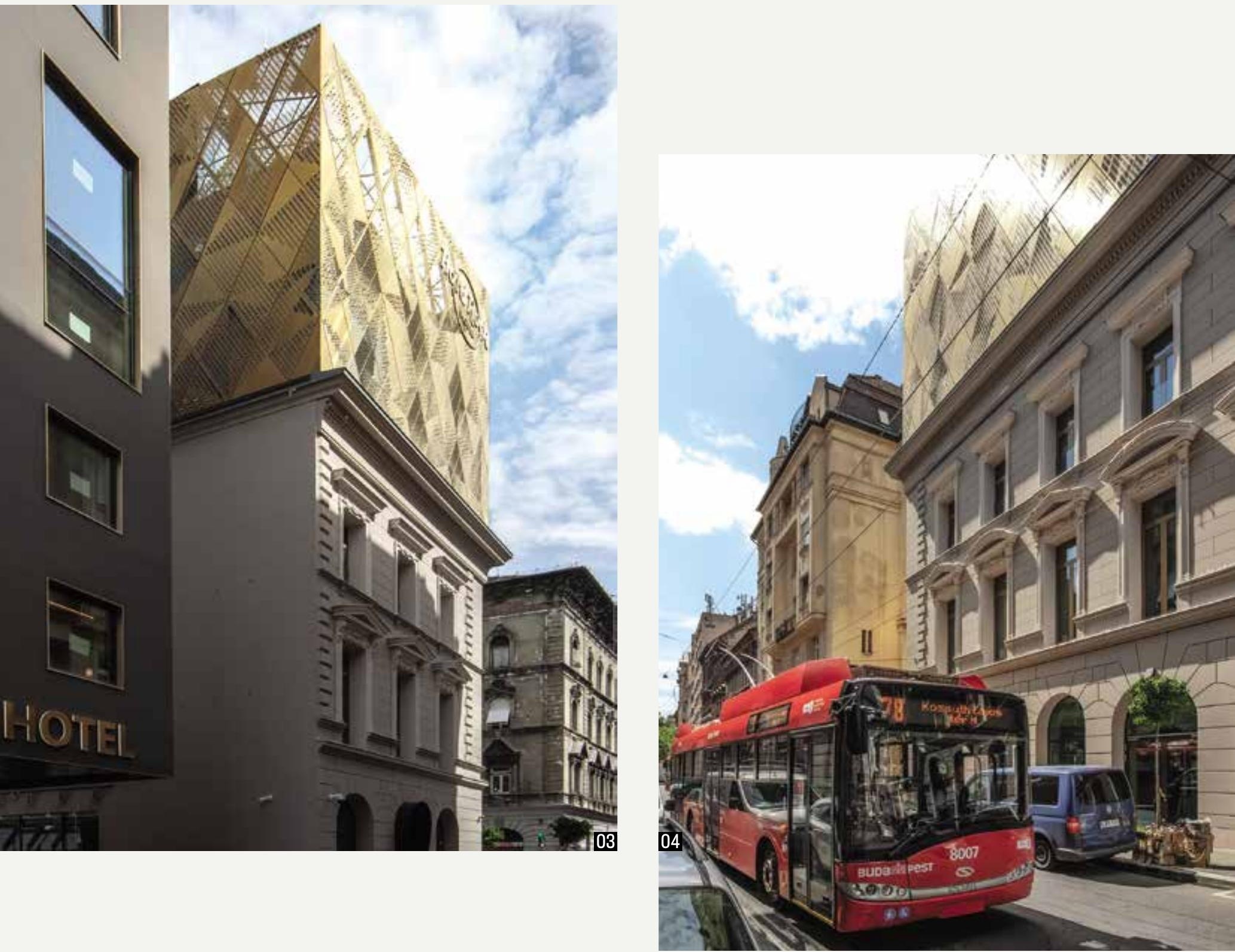

— A felépítmény és a talapzat-ház erős kontrasztja nemcsak a továbbépíthetőség kérdésére adott határozott válasz, hanem az épületegyüttes dramaturgiai hármasságának - régi épület, új szárny, korona - logikus következménye is. Felületi karakterét megtartva, ám szerkesztési elveitől megfosztva vándorolt a hagyományos, vakolt lyukarchitektúra az Ó utcai tömegre, ahol immár az új modulrendszert követve kapott új, homogén skint a századforduló Budapestjének mázaskerámia-fedéseit, kiváltképp a közvetlen előképként kezelt Iparművészeti Múzeum kupolájának színes, absztrakt geometriáját idézve, a szenvtelenül sematikus, analitikus megközelítés és az analogikus tervezés sajátos metszeteként. Alabástrombőrként egyszerre áteresztve és visszatükrözve helyet és időt a szükségszerü építészeti erőszaktétel során. [I]

\section{JELEN}

— Hosszú szünet után 20I4-ben kapott új lendületet a fejlesztés. Számos potenciális üzemeltető sztenderd funkciósémáját sikerült adaptálni, bizonyítva az alapkoncepció életképességét. Végül az ikonikus Hard Rock brand első közép-európai lifestyle hotelje kapott helyet az épületben. _ A nagy, nemzetközi szállodaláncok bevett gyakorlata, hogy az üzemeltető a saját belsőépítészeti vízióját valósítja meg. Ennél az épületnél
Ó utcai homlokzatok Nagymező utcai részlet Földszinti alaprajz Az ó utcai homlokzat terve 


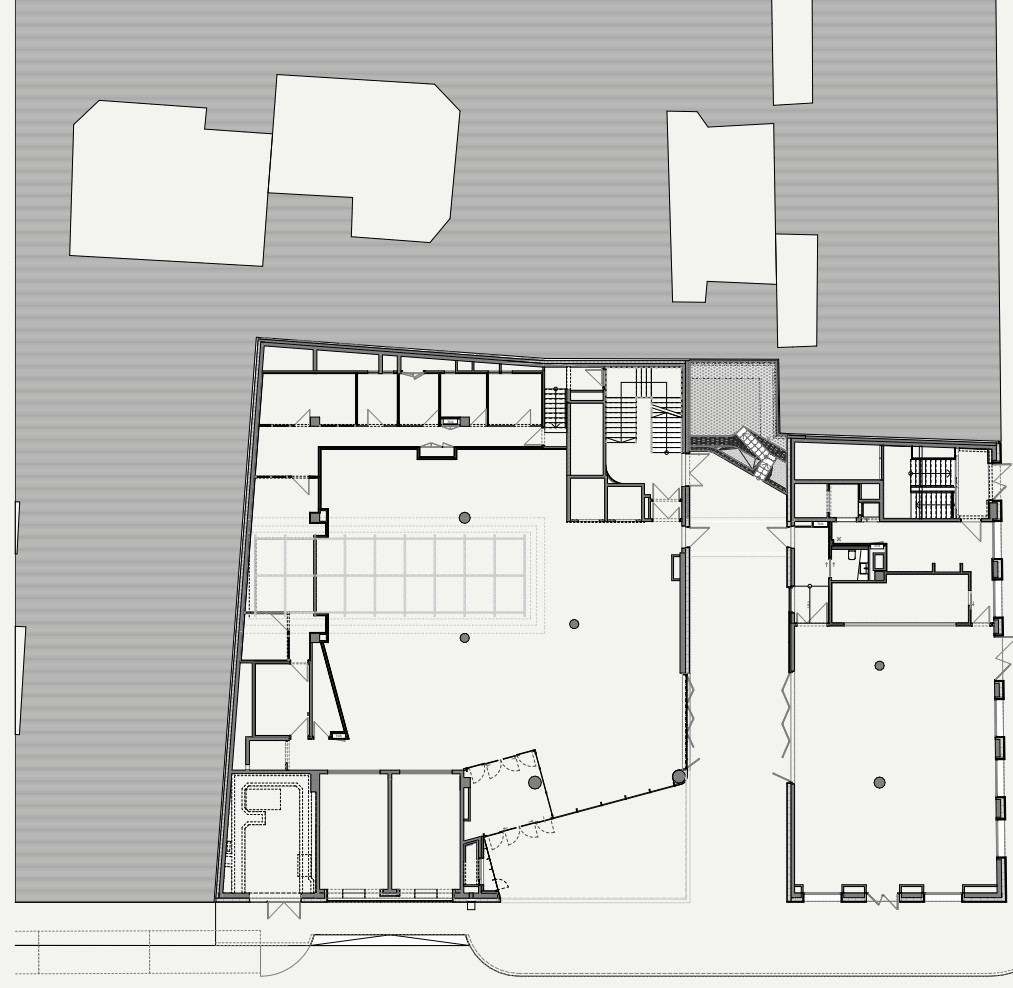

05

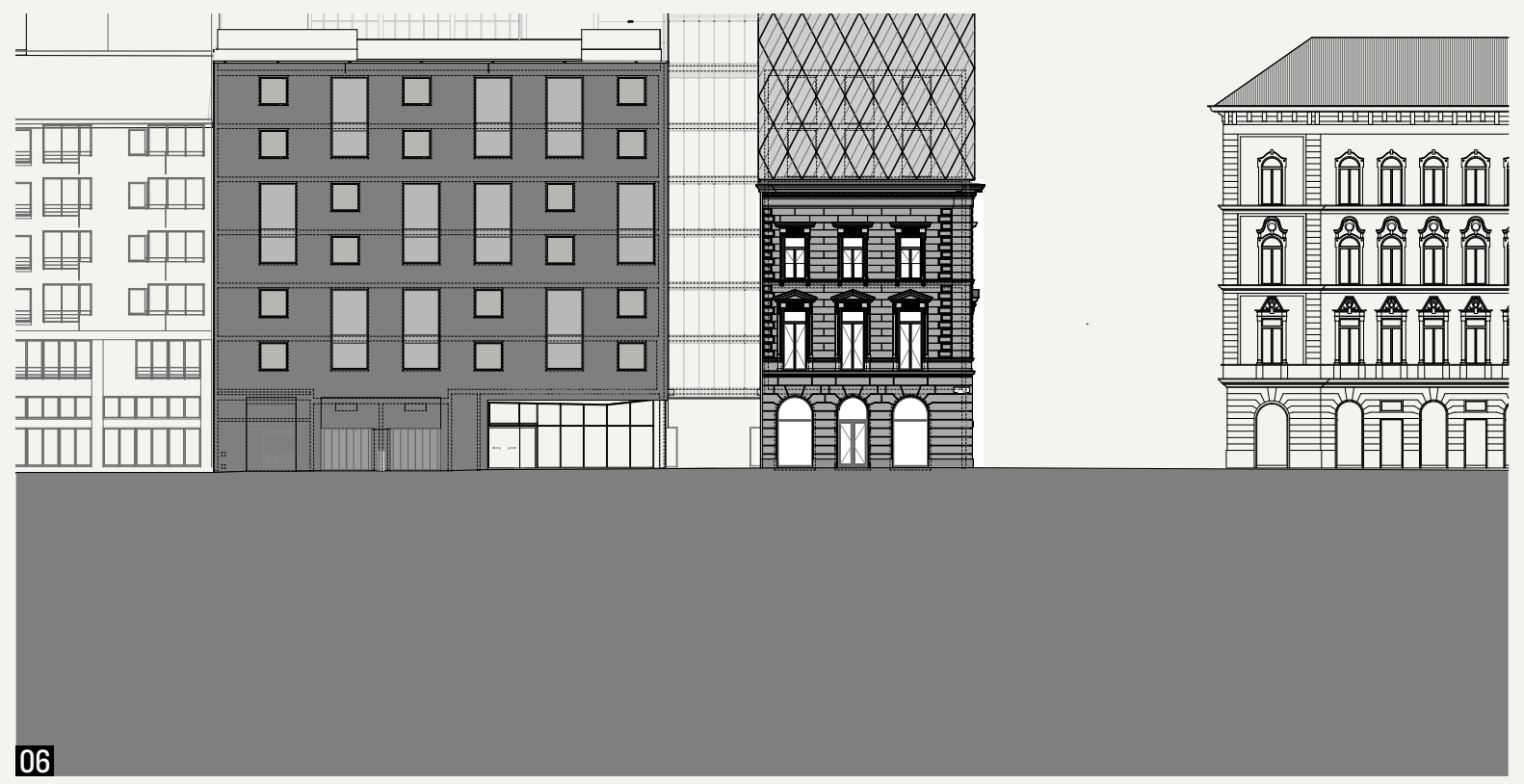

ez fokozottan érvényesült; a ház eredeti építészeti elgondolása, valamint a belső terek kialakítása közötti koncepcionális kapcsolat lehetősége a belsőépítészeti tervezés előrehaladtával fokozatosan elillant.

_ Pedig a branddel megjelenő, divatosan mozgalmas és heterogén belsőépítészeti megoldások izgalmas viszonyrendszert teremthettek volna a feszes külsővel: az alapképlet dramaturgiájára épülő szintaktikus logika átmentésével és a müfajból adódóan extravagáns, szinguláris [2] komponensek ellenpontozó beemelésével többszólamú, de strukturált harmóniákat keresve. 


\title{
ABSTRACTS
}

\author{
ARNÓTH, Ádám: INTERNAL WEALTH \\ Citation: Metszet, Vol 11, No 5 (2020), pp 18-25, DOI: 10.33268/Met.2020.5.1
}

SYNAGOGUE RESTORATION, BUDAPEST, HUNGARY | Restoration Architect: Tamás KöNIG DLA and Péter WAGNER DLA

Originally designed in the Moorish Revival style by Otto Wagner in 1873, this synagogue served as a place of worship for the more conservative members of Budapest's Jewish community. WWII damage left the building

\author{
in a ruinous state, although repairs to the \\ structure did occur, restoration in earnest did \\ not start until 2007. The subsequent works \\ have restored this place of worship to its \\ former splendor and function. Attention payed
}

to the original design, the Torah Ark and unusual use of Moorish decorative elements have helped demonstrate why this building is one of Budapest's significant historic monuments.

\section{LÉVAI, Tamás: TIME TRAVEL}

Citation: Metszet, Vol 11, No 5 (2020), pp 26-31, DOI: 10.33268/Met.2020.5.2

PJ VILLA, KOLOZSVÁR (CLUJ-NAPOCA), ROMANIA | Architect: Miklós PÉTERFFY

Originally designed in 1937, an amazingly exciting period for architecture anywhere, this family home has recently been modernized.

Or has it been restored to its intended form, with updated technology, use of space and materials. Division of spaces has been achieved by feats of geometry on a grand scale, with curved walls and high ceilings developing a perfectionist feeling drawing inspiration from the 1930s desire for luxury. A possible destination for architectural tourism for those departing from Budapest.

\section{CSANÁDY, Pál: MILITARY LEGACY}

Citation: Metszet, Vol 11, No 5 (2020), pp 32-37, DOI: 10.33268/Met.2020.5.3

LMCC ARTS CENTER, GOVERNORS ISLAND, NEW YORK, USA | Restoration Architect: Jay L. BERMAN

A former military base has seen a nineteenthcentury munitions warehouse converted into a venue for the arts by the Lower Manhattan Cultural Council with the intention of creating spaces for temporary exhibitions, studio spaces and public events. As one of the few green park areas of New York this offers a location not only for the arts but also for leisure time activities. The key to this project's success being the fact that a minimum level of work was required due to the architectural strength of the existing building.

\section{WETTSTEIN, Domonkos: SPACE-TIME ILLUSION}

Citation: Metszet, Vol 11, No 5 (2020), pp 38-43, DOI: 10.33268/Met.2020.5.4

STADT CASINO, BASEL, SWITZERLAND | Architects: HERZOG and DE MEURON

The designers of this project have taken an approach similar to that of an Eszterházy novel: travelling through a multifaceted

history of spaces from point of view to point of view. This might be an act of fantasy or irony resulting in a restoration of neobaroque elements, insertion of contemporary interventions, resulting in maintaining the original acoustic quality of the concert hall and improved non-performance circulation areas: foyer, stairwells and corridors which now create a new sequential flow throughout the building complex.

\section{WARE-NAGY, Orsolya: REALISTIC, WALK-IN MODEL, OR THE NEW OLD} Citation: Metszet, Vol 11, No 5 (2020), pp 44-49, DOI: 10.33268/Met.2020.5.5 RESTORATION OF THE HORSE RIDING-HALL, BUDAPEST, HUNGARY | Restoration Architects: Ferenc POTZNER

A key element of the National Hauszmann project to restore or rebuild monumental buildings in Budapest's Castle District includes this Riding-Hall damaged in WWII and finally demolished in the 1950s. Obviously when a building is totally demolished rebuilding to original plans will not occur due to changes in materials, construction methods or statutory requirements. The question arising being that of "is this a faithful reconstruction or a full-scale architectural model" erected in an attempt to satisfy grandiose plans or a false sense of history?

\section{CSONTOS, Györgyi - TÓTH, Timea: ENLIGHTENMENT}

Citation: Metszet, Vol 11, No 5 (2020), pp 50-57, DOI: 10.33268/Met.2020.5.6

CHURCH OF THE STIGMATIZATION OF SAINT FRANCIS, BUDAPEST, HUNGARY | Restoration Architects: Judit Z. HALMÁGYI and Tamás TÓTH

Often religious buildings fall into a state of neglect, here a Roman Catholic Church suffered from a combination of problems: being part of a none too sympathetic urban during the communist era. The architects responsible for the restoration started by making a full digital survey of the building from which analysis of required works could building's fabric, quality of lighting and its place in the urban context have been vastly improved upon.

\section{DOMBÓVÁRI, János: REPAIRED FINALE}

Citation: Metszet, Vol 11, No 5 (2020), pp 58-63, DOI: 10.33268/Met.2020.5.7

\section{HARD ROCK HOTEL, BUDAPEST, HUNGARY Architects: László SZÁSZ and Erzsébet HAJNÁDY}

Following the established business model of the Hard Rock company design concepts are handled by their local franchise partner. Here the decision was made to respect the existing building's elevations, whilst adding a three storey high golden crown that responds to the location, Nagymezó Utca's, Broadway like ambitions. To lift a corner site architecturally with a bold, traditionally, out of context statement. This approach completes the problem of a poorly massed streetscape whilst adding a taste of Rock ' $n$ ' Roll rebellion. 